\title{
The new ethics of abortion
}

Joan Greenwood British Pregnancy Advisory Service, London

The papers included in this supplement were first given at a meeting, The New Ethics of Abortion, organised by the British Pregnancy Advisory Service (BPAS) in Senate House at the University of London on 21 February 2000.

The British Pregnancy Advisory Service is primarily a provider of abortion services. Each year, the organisation provides almost 50,000 abortions, more than half of which are performed on behalf of the National Health Service (NHS), which means they are free of charge to women. We are also a major source of comment to the media on issues relating to unwanted pregnancy and so we frequently face the challenge of debating those who insist that abortion is morally wrong and medically unjustifiable.

The New Ethics of Abortion was organised to provide a forum in which pro-choice and antichoice perspectives could be discussed in an atmosphere of mutual respect. We are aware that advances in technology and changed perspectives on rights - of men, of children, of the fetus, of the disabled-can have an impact on the abortion debate. We are aware that these issues are hotly contested by both those who support and those who oppose the liberal provision of abortion, and we feel that as providers of abortion care to so many women we have an important part to play. The staff at BPAS consultation centres and clinics understand abortion from the perspective of womennot women campaigners (who have their own political agenda) - but women with problem pregnancies in need of abortion care. This is a perspective that is often pushed aside when abortion is regarded as an abstract political or ethical issue.

Abortion has become accepted as a part of British life. Since the 1967 Abortion Act became law in April 1968 more than five million women have benefited from safe, legal abortion in Britain. And, for every woman who has benefited directly from legal abortion, there are thousands more who have been able to enjoy sex, confident that an unwanted pregnancy need not lead to unwanted motherhood.

The British abortion law, which underpins all the contemporary debates, is a complex piece of legislation with a complex history.

David Steel's Bill, which received royal assent on 27 October 1967, made abortion legal in Britain when two doctors agreed in good faith (a) that the continuance of the pregnancy would involve risk to the life of the pregnant women, or risk of injury to the physical or mental health of the pregnant woman or of any existing children in her family, greater than if the pregnancy were terminated; or (b) that there was a substantial risk that if the child were born it would suffer from such physical or mental abnormalities as to be seriously handicapped. The law allowed doctors to take into account the woman's "actual or reasonably foreseeable environment".

Pro-choice critics of the 1967 Abortion Act, which still regulates abortion practice, correctly identify that the legislation did not grant women the right to end an unwanted pregnancy. The act gives doctors the power to decide whether there are medical grounds to support a woman's request for abortion. The law does not allow a woman to end her pregnancy simply because she wants to; there must be evidence that the pregnancy would threaten her physical or mental health or that of her children. As a consequence, women are reliant on the opinion of their doctors.

Nevertheless the law, which appears highly restrictive on paper, can be interpreted liberally by doctors who understand that it is detrimental to a woman's health to force her to endure a pregnancy and become a mother against her will. And, because the law has been interpreted in this way, it has met the needs of many women. The vast majority of abortions end unwanted pregnancies and are carried out by doctors who accept that it is damaging to the mental health of a woman to force her to endure a pregnancy against her will. Indeed, it is arguable that without such liberal interpretation the act would have been unworkable.

The 1967 Act was a product of its times. It reflected and codified the concerns of the $1960 \mathrm{~s}$ and was shaped by the debates and controversies of its day. Public discussion about abortion in the $1960 \mathrm{~s}$ took place in the context of the social reforms and more liberal attitudes that have come to be regarded as characteristic of that period. The sixties was the period in which, in Britain, capital punishment was abolished, homosexual acts between consenting adults in private were decriminalised and censorship in the theatre ended. Divorce became easier to obtain and the contraceptive pill became available. The Labour government elected in 1964 and re-elected in 1966 had, with some success, sought to promote a consensus that social conflicts and problems could be resolved through welfare policies. Abortion at that time was framed 
as a welfare policy - a means to help women who, for one reason or another, could not cope with their pregnancy.

In part the Act was a response to the existing reality of abortion outside the law. Estimates as to how many illegal abortions occurred each year vary from 15,000 to 150,000 but there is no dispute that a large number of pregnancies were ended in this way. Many women, especially those from working class communities, relied on "back-street" abortions and traditional ways to induce menstruation with variable success and safety. It was estimated in 1959 that the treatment of spontaneous and induced abortion accounted for one fifth of gynaecological admissions treated within the NHS. However, throughout the 1960s, abortion was increasingly carried out by "respectable" doctors who believed they could defend their actions. Although abortion was illegal, a defence was available if the act was performed, in good faith, for the purpose of preserving the life of the mother. The Bourne judgment of 1938 affirmed that if an abortion was performed because the continuance of the pregnancy would make the woman a "physical or mental wreck" the doctor was "preserving the life of the mother". ${ }^{2}$

Although many doctors still refused to sanction abortion, by 1967 it has been estimated that almost 10,000 abortions a year were being provided by NHS gynaecologists. In the private sector, abortion was emerging as a lucrative source of income for those prepared to exploit desperate women by charging high fees.

The law was, and was perceived to be, unclear, inadequate and in need of reform. Not surprisingly there was some disagreement about what such reform should be. The seminal account, Abortion Law Reformed by Madeleine Simms and Keith Hindell describes in great detail the different expectations individuals and organisations had of David Steel's Bill. ${ }^{3}$ Some viewed it as an opportunity to regulate and restrict abortion, perhaps by limiting those who could perform it to consultants, or by limiting where it could be performed to NHS premises. Others saw it as an important clarification of the circumstances in which pregnancies might or might not be ended and yet others as a means to provide caring doctors with protection from prosecution for humane acts that would give women with unwanted pregnancies a chance to regain control of their lives.

The 1967 Abortion Act has served women reasonably well for the last three decades. Women still experience many problems obtaining abortion in Britain but these are largely caused by problems in the organisation and funding of services rather than by the law itself. The main difficulty women face is that abortion is still stigmatised and not perceived by some health professionals, doctors, and managers as an essential service that should be available within the NHS. Health authorities rarely meet the local need for abortion, leaving women to face either arbitrary rationing criteria or waiting lists.
Certain elements of the law are irritating and anachronistic. The insistence that two doctors must certify the grounds on which the abortion is performed is needlessly bureaucratic and can cause delays in the assessment process. The absence of clear provision for abortion on request in early pregnancy means that women must justify their need in a way that many find to be degrading and intrusive.

There are, however, some aspects of the law that have been of great benefit to women and their doctors. The British law, unlike that of many countries, does not change the criteria for abortion at 12 weeks so that abortion remains available to protect the woman's health up to 24 weeks. In spite of this greater freedom almost 90 per cent of abortions are performed before 13 weeks and fewer than two per cent take place after 19 weeks. The proportion done in the first three months has tended to rise rather than to fall. The relatively liberal provision after the first trimester has been of enormous benefit for those who would not, for a variety of reasons beyond their control, have been able to take advantage of earlier procedures. The small proportion of second trimester abortions has also provided a clear demonstration to the world that legal provision of late abortion does not mean that large numbers of late abortions will occur.

The social significance of the 1967 Abortion Act, and its benefits to women's lives, can be most easily seen in problems faced by women in Northern Ireland - a section of the UK to which the Abortion Act does not apply. In Northern Ireland abortion is regulated by the statute and case laws that applied to the rest of the UK before the Steel bill was passed. Northern Ireland in the 1990s, however, provides a very different social climate from that of Britain in the 1960s and consequently doctors there interpret the law conservatively. Women in Northern Ireland are forced either to accept unwanted pregnancies or travel to clinics in Britain.

It is an indication of the strength and practicability of the 1967 Act that it has endured over three decades of considerable social change with so little amendment. In 1990, a comprehensive codification of law relating to the embryo and artificially assisted reproduction provided an opportunity for parliament to review the abortion law. Few changes were made. The upper limit for abortions to protect physical or mental health was clarified as 24 weeks but the gestation limit was removed when termination was necessary because the pregnancy threatened the woman's life or would result in grave permanent damage to her health, or when there was a substantial risk that the fetus was seriously abnormal.

Although the law has not changed, however, the debates and discussions on abortion as an issue have. We need to meet the challenge of considering these new issues and deciding their relevance to abortion provision.

As Britain's leading provider of abortion services our work is affected by changes in public and political opinion. We need to understand the 
contemporary debates and we believe we have an important contribution to make to them. It is in this spirit that the following papers are published.

Foan Greenwood, OBE, is Chairman of the British Pregnancy Advisory Service, London. BPAS would like to extend grateful thanks to Professor David B Morton, Head of the Centre for Biomedical Ethics, Division of Primary Care, Public and Occupational Health, at the University of Birmingham for his invaluable help in editing the papers included in this supplement.

\section{References}

1 Committee on the Working of the Abortion Act (Lane Committee). Report of the Committee on the Working of the Abortion Act. London: HMSO, 1974: vol 1, para 35.

2 R v Bourne [1938] 3 All ER 615.

3 Simms M, Hindell K. Abortion law reformed. London: Peter Owen, 1971 .

\section{Incapacity and Consent}

Tuesday 16 October 2001

Cafe Royal, London

This highly respected $3 \mathrm{rd}$ annual conference will examine the latest guidance from the Department of Health Consent Group as well as changes to the Mental Health and Learning Disability Services. In a climate of increasing litigation it is vital to equip yourself to make the best decisions; this conference aims to do just that. For further information please contact Katy Henson. Telephone: 0207453 2167. Fax: 0207453 2090. Email: katy.henson@informa.com 